\title{
Teaching in Universities: The Power to Touch
}

\author{
DIANNE L. COMMON*
}

And gladly would he learn and gladly teach - CHAUCER

\section{THE IMPORTANCE OF TEACHING}

Universities, as Taylor (1986) rightfully points out, are "troubled institutions" functioning in troubled times. The only clearly apparent constant in the current rather anxiety laden debates about the proper and desirable activities of universities in Canada has to do with teaching. Few would argue against the singular importance of teaching. Teaching is the most visible and recognizable activity in which those who work in universities engage. It is what occurs most often and to study with teachers is the reason why most of our students come to university. It is what requires the most physical space, and the most of both student and professor time. Universities would not be universities but, rather, research institutes if teaching were not to occur.

Nationally and internationally, good universities are recognized because of the quality of their researchers and their research programs. Regionally, good universities are known because of the quality of their teachers and their instructional, usually undergraduate, programs. Most universities are populated by students from their immediate region. This is a significant observation not lost upon policy makers and university administrators. Not only is it clearly desirable, but it is in the best interest of the university to have quality teaching as a goal, as central to its mission, and as an accomplishment.

The pursuit of quality teaching is a relatively recent phenomenon in our universities and which has, according to Donald (1986), a "mottled history in Canada." (p.77). The activities have been, for the most part, sporadic, uneven, and aimed at a variety of targets. Twelve years ago no university in Canada gave awards for excellence in teaching (Donald,1986). Not all universities give such awards today.

In order to improve the quality of teaching in universities, and to improve the reputation of their universities in their regions, administrators have made concerted moves to eliminate poor teachers from their faculties, to measure and to 
evaluate teaching performance, to reward good teaching in terms of promotion and other positive sanctions, to offer sabbaticals and study leaves in order to refresh stale teachers, and to provide training services for professors who wish to improve their teaching.

Many universities have what are generally called offices for teaching services which typically provide professors with opportunities to learn about the technological dimension of teaching, the 'how to do' dimension which includes activities such as media use, unit planning by objectives, questioning techniques, test design and construction, and microteaching. The assumption is that there is some connection between the acquisition of technological types of teaching techniques and improved quality in instruction and student achievement.

While there is some evidence that there is a correlation between certain teaching techniques in direct instruction and improved achievement on basic skill tests by children, there is no evidence of which I am aware that shows a relationship between certain teaching techniques and academic achievement by university students. However, the strategies that have come to comprise many of the activities of offices of teaching services are drawn heavily from the rapidly growing literature on "effective teaching" that is produced largely in the United States. Generally ignored are the many criticisms directed at this literature in terms of its research designs and populations, its subject matter or content free character, and its limited generalizability. 'This condition of university offices of teaching services is further compounded by the paucity of literature on teaching effectiveness in higher education. The extant literature is replete with studies on student satisfaction measures and instructor performance indicators, and quite devoid of studies on the nature of teaching in higher education and what the constituents of teaching are. ${ }^{2}$ Offices of teaching services primarily focus on the improvement of the techniques of teaching, but technique is only one constituent of teaching and quite possibly might be a poor second cousin to other more important matters. ${ }^{3}$

Some of the teaching in our universities is terribly good; some of it is tragically bad. Most, if not all professors and their students are able to distinguish with confidence between the good and the bad. But, few are those who have clearly articulated the difference and have been able to bring some order to the nature of good or effective teaching. My objective in this article is to bring some order to, to offer a conceptualization of, the nature of teaching in higher education. I believe such an objective is important because improving the quality of teaching must be a focus for the mission of our universities. Only by understanding the nature of teaching better, will university administrators and professors be able to provide more appropriate and different opportunities for improving teaching in their offices of teaching services.

In order to accomplish this objective, I have engaged in three activities. First, I have reviewed a considerable body of research studies on teaching in higher education in order to identify what was common among them in terms of factors 
that were related in some way to what was judged to be good or effective teaching. Second, I have analyzed a number of cases of what were acclaimed to be master teachers. These cases were drawn from the works of Epstein (1981), Eble (1986), Rice (1986), and Beidler (1986), and my own experiences at four Canadian universities. Finally, I brought some order to all of this and developed a conceptualization on effective teaching in higher education.

\section{ACCORDING TO RESEARCH}

Some researchers, such as Dunkin (1986), have attempted to develop a position on the nature of university teaching. The focus, generally, has been on the system of teaching and process-product, process-context, presage-process relationships and process occurrences. Nonetheless, Dunkin himself acknowledges the limitations of such types of studies because they do not reveal what teachers do in their teaching situations. That is, they do not reveal the nature of teaching. When considering the issue of defining effective teaching, Murray (1985) put it this way:

"Despite widespread use of student instructional ratings, little is known about the specific things that teachers receiving high or low ratings actually do in the college classroom." (p. 22)

Understanding what teachers actually do must stem from some understanding of what teaching is. To understand teaching, it is necessary to glean not only the whole of it in context, but its constituents as well. Dunkin (1986) proposes that such understanding will be likely if we engage in observational studies of teachers in situ. Beidler (1986) seems to suggest that such understanding will come from the analysis of teaching masters by their fellow teaching masters, this to be followed by a further critical analysis by yet other masters, those who are recognized connoisseurs of teaching. This is similar to the approach adopted by Epstein (1981) and Eble (1986) in their attempts to 'paint the portraits' of great teachers.

Three notable conceptualizations of teaching in higher education are those of Sheffield (1974), Feldman (1976), and Seldin (1980). All identified dominant qualities of an effective teacher, but were limited in their conceptualizations because they did not focus on the activity of teaching itself. By paying attention not only to the teacher, but also to teaching, we will attend not only to the qualities of the teacher who is effective, but also to the qualities of the setting which is characterized by effective teaching. It is my consideration not so much of the qualities of the effective teacher, but rather of the qualities of the effective setting for teaching that takes my conceptualization beyond and in a different direction from those of Feldman, Seldin, Rice, Eble, Sheffield, Epstein, and Beidler. It is my objective to provide a different way of thinking about and, in the end, of understanding teaching and how to enable its improvement. 


\section{THE CHARACTERISTICS OF THE TEACHING SETTING}

A setting, explains Sarason (1982), is created when people come together in order to relate in certain ways for certain purposes. The marriage setting consists of particular types of relationships that have particular types of goals which are distinctly different from those characteristic of a teaching setting. There are some activities that are clearly appropriate to one and not to the other. A setting occurs in an environment. In this case, the setting for teaching is the university. A setting obviously is not independent of its environment, but is clearly shaped in some ways by it.

When we think of a setting, we must think of the people composing it. A teaching setting consists of teachers and students. Teaching is effective when the activities have been appropriate to the purposes and the purposes that each participant had are met. The indicators of effective teaching, then, should be drawn from the characteristics of the relationships, the purposes held by the people involved, and the degree to which the relationships enabled the purposes to be achieved.

In starting to analyze effective teaching, the characteristics of the relationships are our proper target. There are five characteristics which, if present, are indicators of an effective teaching setting. These are: 1) rational instructional practice; 2) decentralized management; 3 ) continuous progress; 4) summative evaluation; 5) active engagement. All indicators are necessary for an effective setting. I will now discuss each characteristic in turn.

\section{1) Rational Instructional Practice}

Research studies and good common sense will tell us thát there have to be some order and orderliness to any effective teaching setting. This is not to say that there are clear beginnings and ends and that they are the same no matter what the subject matter. Rather, the members of the setting, teachers and students, must perceive the order and the orderliness, must understand why they are the way they are, and how they affect what they do. There are four factors that come to shape both the order and the orderliness. They are: the scope of both the content to be taught and learned and of the instructional activities; the sequence of the content and instructional activities; the pace and rhythm of the activities; the transitions between activities. The latter, the transitions and their smoothness are the grease that make sequence recognizable and happen, and that make the pace and rhythm functional. It is the sense of order and orderliness here that makes the teaching practice rational, not its intrinsic logic, fixed points, or prescribed sequence, beginnings, or endings.

\section{2) Decentralized Management}

Both members in the teaching setting in universities are adults. Both members are aware of the respective power each member has, and the concomitant powerless- 
ness of each. To that end, for the setting to be a just one in which power is distributed according to the responsibility and accountability of each, each must be able to exercise that power through the creation of conditions necessary for such exercise of power. One such condition clearly is the management of the context in which the setting for teaching occurs. For both to engage in managing, the management of the setting must be shared, and hence will become decentralized. Teachers and students need to be able to regulate how the other as well as themselves relate within the teaching setting, with the foci for this regulation being largely the order and the orderliness of the instructional practice.

\section{3) Continuous Progress}

A second condition that is necessary for the exercise of both members' power in the setting is the continuous progress of both teachers and students. Both, as adults, expect to learn during the duration of the setting, and both expect to be different at the end of the experience. Each requires the opportunities to try, to fail, to succeed, to repeat. During the life of the setting, students and teachers both expect to be judged according to criteria that are unique or idiosyncratic to each during the setting. Teachers as they work expect to be judged in terms of their stage of development within the setting. So also do students. Further, each student expects to be judged on criteria idiosyncratic to each. If there are ten students in the setting, then each expects to be judged according to his or her own appropriate standards of accomplishment. During the continuous progress of the setting, there are no failures, only learning opportunities. Doing it again to 'get it better' or 'right' are the most generalized objectives appropriate during this period of the growth and maturation of the setting.

\section{4) Summative Evaluation}

Continuous progress evaluation processes are not appropriate when the setting has either matured or developed to its expected finishing or closing point. At the time of maturation or closure; the criteria for judgement and evaluation must become common for all and to all. During the development of the setting, the criteria for determining achievement, while idiosyncratic, enable both teachers and students to make formative judgments about their worth at given points in time. At the end point, or the point which is deemed to be the maturation point, which may occur some time before the end, the criteria for judgement and evaluation are drawn from general and shared standards for quality and are determined primarily by the personal standards of the professor, the standards of the faculty or university, and the standards intrinsic to excellence or to accomplishment in the field of study or discipline. At the maturation point, the evaluation is summative and common to all. At the maturation point, common or discipline wide tests or examinations are appropriate, as are common or university wide teacher performance measures and forms. 


\section{5) Active Engagement}

Engagement is what makes a teaching setting work. Engagement occurs when students and teachers interact. Active engagement occurs when teachers and students share the same goals and relate in appropriate ways to reach those goals. Active engagement depends upon the willingness and ability of students to become engaged and the ability of the teachers to earn the consent of the students to participate in the activities of the setting.

Students will consent for three reasons. One, because they believe that the substance of the engagement has worth. That substance is, of course, the content or subject matter. They want to learn, say, engineering, no matter who is teaching it. Two, they will consent because they believe that the teacher has worth and is worthy of their consent. For example, they may believe that the teacher has worth because he or she cares about them, or because the teacher has charisma. They value the other member of the setting, the teacher, in other words, and only vicariously value the content. Three, they consent for utilitarian reasons such as having to pass, take an elective or prerequisite, and so on. However, this last reason results in a false engagement because their interaction in the end is one only with the content, if that, and occurs largely outside of the setting. The setting in this instance breaks down because goals are not shared and interactions are not legitimate. The teaching becomes ineffective, and quite often, so does learning.

I am not suggesting here that the teacher involved in the teaching setting needs to be engaging. There is no strong evidence from research that would suggest that there are some personality traits, such as good humour, that consistently correlate with effective teaching (Feldman, 1976; Kaplan \& Pascoe 1977). What one student might find engaging in Professor A might cause quite the opposite reaction in another student. What personality traits that law students might find engaging in, say, their professor of Contract Law might not be those that undergraduate students in education would find endearing at all. If the students are not engaged, then the content, no matter how rich, will not be learned. As Murray (1985) put it,

"...behaviors aimed at structuring material or stimulating independent thought can be expected to be successful only to the extent that student attention has already been effectively engaged." (p. 29)

\section{CONCLUSION}

In an attempt to bring some definition to effective teaching in universities, there are two concluding points to be made. One is brief. The other is less so.

Briefly then, an effective teacher is one who can bring about a setting in which the five characteristics are clearly evident to all members of the setting and, as well, to external observers. Which of the characteristics should predominate is unclear and probably this is quite as it should be. In some studies, such as that of Cohen (1981); rational instructional practice predominated. If I infer correctly from Donald's (1985) work, the dominance or mix of characteristics could vary according to subject matter. She points out that 
"...students in the sciences note course structure and organization, while in the humanities they remember enthusiasm. This distinction is consistent with expected differences across disciplines, that is, with the characteristics of the disciplinary subcultures, sciences being more tightly structured and humanities more divergent." (p. 10)

The second point is more complex and subtle. What is coming clear is that there is no one definition of a good or effective teacher independent of the character of the setting which that teacher creates. It requires both members, teacher and students, to create settings for teaching. Nonetheless, the dominant actor must be the teacher. If that is not the case, and the dominant actors become the students, then the teacher has forfeited his or her role. That might not be bad as long as the role transfer was agreed upon and does not represent a coup. Teachers initiate the creation of teaching settings, maintain the settings, and bring them to a close. Those are their most important tasks.

It is also just as clear that effective or master teachers are not born, but rather are made, or better still, make effective teaching settings. ${ }^{4}$ Master teachers come in all shapes and heights, sexes and colours. What is common to all of them is that they know something important and are able not only to convince others that they also should know it, but that they are able to enable those others to learn it. As Beidler (1986) so ably and succinctly put it, effective teachers in our universities have "...the power to touch human lives" (p. 4). There can be no greater responsibility and no more worthy professional endeavour. It is only vital that we understand this power, shepherd it with great care, and use it wisely. Improving the quality of our teaching in our universities has to become the first order of business because it is, quite simply, our biggest and most important business.

\section{NOTES}

1. For an overview of this literature see Wittrock, M.C. (ed.) (1986) Handbook of Research on Teaching. New York: Macmillan.

2. Based on a review of the quarterly publication, Higher Education Abstracts, Volumes 19, 20,21, 22, and the reference list provided by M. J. Dunkin (1986). "Research on Teaching in Higher Education", in Wittrock, M.C. (ed.) (1986) Ibid:

3. Newton, R.R. "Can a Performance Based Approach be Adapted to Higher Education?" CAUT Bulletin as cited in Donald and Sullivan (eds.) (1985).

4. Two excellent case studies to read in order to have exemplars to underscore my point are found in Jackson's article in Change.

\section{BIBLIOGRAPHY}

Bassis, M. S. \& Guskin, A. E. (1986, July/August). "Building Quality: Research and the Regional Instructions." Change, 18 (4) 57-66.

Bailey, A. L. (1986, July/August), "Faculty Leaders in Profile." Change, 18 (4). 24-32.

Beidler, P. G. (ed.) (1986). Distinguished Teachers on Effective Teaching. San Francisco: Jossey-Bass.

Cohen, P. A. (1981) "Student Ratings of Instruction and Student Achievement: A Meta Analysis of Multisection Validity Studies." Review of Educational Research, 51, 281-309. 
Donald, J. G. (1985), "The State of Research on University Teaching Effectiveness." in J. C. Donald and A. M. Sullivan (eds). Using Research to Improve Teaching. San Francisco: Jossey-Bass Inc.

Donald, J. G. (1986). "Teaching and Learning in Higher Education in Canada: Changes over the Last Decade." The Canadian Journal of Higher Education, XVI (3), 77-84.

Donald, J. G. and Sullivan, A. (eds.) (1985). Using Research to Improve Teaching. London: Jossey-Bass.

Dunkin, M. J. (1986) "Research on Teaching in Higher Education," in Wittrock, M.C. (ed), Handbook of Research on Teaching. New York: Macmillan.

Eble, K. E. (1986, July/August), "A Group Portrait." Change, 18 (4), 21-23.

Epstein, J. (1981). Masters: Portraits of Great Teachers. New York: Basic Books.

Feldman, K. A. (1976). "Grades and College Students' Evaluations of their Courses and Teachers." Research in Higher Education, 4, 169-111.

Feldman, K. A. (1976). "The Superior College Teacher from the Students' View." Research in Higher Education, 5 (3), 243-288.

Feldman, K. A. (1986). "The Perceived Instructional Effectiveness of College Teachers as Related to their Personality and Attitudinal Characteristics: A Review and Synthesis." Research in Higher Education, 24 (2), 139-213.

Jackson, G. A. (1986, May/June). "Technology and Pedagogy: Making the Right Match is Vital." Change, 18 (3), 52-57.

Kaplan, R., and Pascoe, G. (1977). "Humorous Lectures and Humorous Examples: Some Effects upon Comprehension and Retention." Journal of Educational Psychology, 69, 61-65.

Murray, H. G. (1985). "Classroom Teaching Behaviors Related to College Teaching Effectiveness." in Donald, J. G. \& Sullivan, A.M. (eds.). Using Research to Improve Teaching: New Directions for Teaching and Learning. San Francisco: Jossey-Bass.

Perry, R. P. (1985). "Instructor Expressiveness: Implications for Improving Teaching." in Donald, J. G. \& Sullivan, A.M., (eds) Using Research to Improve Teaching: New Directions for Teaching and Learning. San Francisco: Jossey-Bass.

Rice, R. E. (1986, July/August). "Those Who Gladly Serve." Change, 18 (4), 13-20.

Sarason, S. (1982). The Creation of Settings and Future Societies. San Francisco: Jossey-Bass.

Seldin, P. (1980). Successful Faculty Evaluation Programs. New York: Coventry Press.

Sheffield, E. F. (ed.) (1974). Teaching in the Universities: No One Way. Montreal: McGill-Queens University Press.

Stipek, D. J. \& Weisz, J. R. (1981). "Perceived Control and Academic Achievement." Review of' Educational Research, 51, 101-137

Taylor, W. (1986, November). "Crisis in the Universities." The OECD Observer. 143, 14-16.

Tom, F. K. T. \& Cushman, H. R. (1975). "The Cornell Diagnostic Observation and Reporting System for Student Description of College Teaching." Search, 5 (8), 1-27.

Wlodkowski, R. J. (1985). Enhancing Adult Motivation to Learn. San Francisco: Jossey-Bass. 